\title{
The Influence of Diglossia on Syntactic Proficiency in Modern Standard Arabic among Regular and Struggling Readers
}

\author{
Salim Abu-Rabia1, Eman Sarsour Kedan'1, Haneen Wattad ${ }^{2}$ \\ ${ }^{1}$ Faculty of Education, University of Haifa, Haifa, Israel \\ ${ }^{2} \mathrm{Al}$ Qasemi Academic College, Baka, Israel \\ Email: salimar@edu.haifa.ac.il
}

How to cite this paper: Abu-Rabia, S., Kedan, E. S., \& Wattad, H. (2022). The Influence of Diglossia on Syntactic Proficiency in Modern Standard Arabic among Regular and Struggling Readers. Creative Education, 13, 252-282

https://doi.org/10.4236/ce.2022.131016

Received: December 15, 2021

Accepted: January 25, 2022

Published: January 28, 2022

Copyright () 2022 by author(s) and Scientific Research Publishing Inc. This work is licensed under the Creative Commons Attribution International License (CC BY 4.0).

http://creativecommons.org/licenses/by/4.0/

(c) (i) Open Access

\begin{abstract}
This study examines the influence of diglossia on syntactic proficiency in Modern Standard Arabic (MSA) among 63 fourth-graders in central Israel, divided into two groups: regular and struggling. They were given three examinations constructed especially for this study: translating sentences from Spoken Arabic Vernacular (SAV) into MSA, a cloze test, and an oral exam, in which the pupils were asked to describe pictures in MSA. The findings revealed errors in the use of connectives, the use of prepositions, sentence integrity, and verb conjugation. No significant differences were found between regular and struggling pupils in average test scores in terms of errors in syntactic elements. In using prepositions, regular pupils made more errors than did struggling pupils; this was because the latter did not answer questions relating to this element. Several factors explain the effect of diglossia on syntactic proficiency: the similarity of MSA and SAV, the influence of the surroundings, scanty reading of books, the teaching methods used in Arab schools, the influence of Hebrew on the Arab student, and the lack of encouragement from the establishment and the education system. Future research should investigate this effect on a larger sample in order to obtain more representative outcomes.
\end{abstract}

\section{Keywords}

Diglossia, Struggling Pupils, Regular Pupils, Syntactic Proficiency, Spoken Arabic Vernacular, Modern Standard Arabic

\section{Introduction}

The in-depth linguistic analysis of Spoken Arabic Vernacular (SAV) and Mod- 
ern Standard Arabic (MSA) reveals differences in all areas of the language, including the phonological, the morpho-syntactic, and the lexical-semantic fields (Maamouri, 1998).

Researchers have noticed that SAV has an adverse effect on the development of reading. Children speak SAV until preschool age and, therefore, find it difficult to construct phonological representations of MSA words in the early school grades (Saiegh-Haddad et al., 2011; Saiegh-Haddad, 2003, 2004, 2007).

The scientific literature indicates that Arabic diglossia has a definitive impact on reading and basic linguistic skills due to the gulf between the vernacular form, acquired in childhood, and Modern Standard Arabic, mastered later on. Thus far, the effect of this diglossia on syntactic proficiency in MSA has not been examined, and here is where this study will make its contribution.

The phenomenon of diglossia has been copiously examined in the research literature, particularly in the context of the Arabic language. The studies show that diglossia affects accuracy in reading and writing and that spoken Arabic has an adverse effect on the development of reading. The reason is that children up to preschool age use Spoken Arabic Vernacular (SAV) and find it difficult to construct phonological representations of words in Modern Standard Arabic (MSA) in the lower school grades. In this respect, the cognitive systems of children and adolescents relate to the two strata of Arabic as they would to two different languages (Saiegh-Haddad, 2003, 2007). However, the question of syntax and sentence structure has not been examined thus far, and this is where the study will make its contribution.

Arabic speakers are typical examples of practitioners of diglossia, in which two different linguistic codes of one language-vernacular Arabic, acquired first, and literary Arabic (hereinafter also: standard Arabic), acquired at a later stageencounter each other.

The treatment of diglossia in the research literature shows that this situation causes difficulty among Arabic speakers and impedes their acquisition of basic skills relative to speakers of other languages (Saiegh-Haddad, Levin, Hende, \& Ziv, 2011; Asaad \& Eviatar, 2014). The specific characteristics of the Arabic orthographic system are more complex than are those of its counterparts in other languages. Arabic characters vary in form depending on their position within the word and are accompanied by vowels indicated by diacritics (see details below). It is this visual complexity that explains why young children find it difficult to acquire reading proficiency.

Notwithstanding the considerable attention that the research literature has paid to Arabic diglossia, the effects of the diglossia on syntactic proficiency in standard Arabic have not been examined thus far.

The purpose of this study is to examine the effects of diglossia on syntactic proficiency in standard Arabic among regular and struggling readers.

\section{Literature Review}

\section{What Is Reading?}


Reading is the ability to encode phonetic information into words that have meaning and that, in combination, allow one to comprehend a complete text. The acquisition of reading proficiency in a second language entails abilities based on phonological processing, such as synthesis and analysis of phonetic information, and capabilities such as performative memory (Herts, Ibrahim, \& Shibel, 2014).

The process of reading in different languages is affected, among other things, by the specific characteristics of the orthographic system of each language. The importance of orthographic and phonological representations varies from one language to the next. Consequently, readers develop special cognitive mechanisms that allow them to cope effectively with the specific orthographic properties of the language that they are learning to read (Asaad \& Eviatar, 2014).

Ibrahim et al. (Abu-Ahmad, Ibrahim, \& Share, 2014) claim that reading and writing proficiency in one's first language helps one to acquire a second language due to the interlinguistic transferability of reading proficiencies such as phonological awareness, print perception, knowledge of spelling, and general knowledge. It is also found that phonological awareness in one's first language can predict the identification of words and coding proficiencies in the second language. Children who develop literacy proficiency in their mother tongue make faster progress in a second language by transferring their skills from one language to the other. This transfer finds expression only if the learner is adequately exposed to the second language and is motivated to learn it.

To read aloud successfully, one must translate items in the written text into specific phonetic sounds that ultimately manifest as spoken words. Accordingly, to learn to read one needs a system of mapping between chains of printed words and their corresponding phonological sequences. This process, known as "phonological reconstruction", is an inseparable part of the successful acquisition of reading proficiency (Saiegh-Haddad \& Schiff, 2017).

\section{Developmental Stages in the Reading of Words}

The reading process evolves in three stages: identification of the word, spontaneity, and celerity (Ehri, 1998; Shany, Bar-On, \& Katzir, 2012). In the first stages of reading, readers identify words more on the basis of sublexical processes than on lexical ones. Only after understanding the meaning can one attain spontaneity in reading larger orthographic units. When skilled readers approach a text, they can call on a wealth of orthographic representations that allow them to bring self-teaching mechanisms into play. The duration of the word-identification stage may vary among learners of different orthographies. Studies on this topic emphasise the existence of differences among orthographies in terms of their depth, a variable that affects the rate of reading acquisition in these languages (Caravolas, Lervag, Defior, Malkova, \& Hulme, 2013; Plaut, McClelland, Siedenberg, \& Patterson, 1996; Serrano \& Defior, 2008).

The main approaches to processing assume the existence of general cognitive processes that affect reading in alphabetic orthographies. Content-dependent approaches assume that various cognitive factors may contribute differentially to 
reading in accordance with the specific properties and the transparency of the orthographic systems (Share, 2008; Frost, 1998; Van Orden, Pennington, \& Stone, 1990). This view seems especially relevant in respect of Arabic, which has unique characteristics that set it apart from other languages (Asadi, Ibrahim, Khateb, \& Taha, 2017).

One may hypothesise that the greatest difficulty in reading Arabic flows from the fact that Arabic words are morphologically denser than are words in other languages. When morphologically complex words are read, the specific representation of vowels is essential to determine and understand their exact meaning (Abu-Ahmad et al., 2014). Ibrahim (2009a) stresses that morpho-lexical structure (morphological density, relatively long words, lexical ambiguity) contributes significantly to differences between readers of Arabic and readers of other languages.

The Arabic Orthographic System

The specific characteristics of the Arabic orthographic system are considered more complex than those of counterparts in other languages. This alphabetical system is written from right to left and comprises twenty-eight characters that represent consonants, three of which also represent long vowels (Taha, 2013). Short vowels are added as diacritical marks over and under the characters, creating some degree of visual complexity.

Arabic characters vary in form. Each has more than one written form, depending on its position in the word: beginning, middle, or end. The main form of the character, however, is preserved in all cases. Six characters $(j, 1,9, د, j$, connect from the right; each has two forms. The other twenty-two characters may connect from either side; each of them has four forms. Likewise, the characters look much the same because several have the same basic form and are differentiated by the addition of one to three dots over, within, or under them (Abu-Rabia \& Awwad, 2004; Saiegh-Haddad \& Henkin-Roitfarb, 2014).

Apart from the varying forms of the characters, vowels are important characteristics of Arabic orthography. There are three long vowels and three short

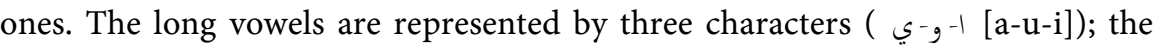
short ones are represented by diacritics over or under the characters. They are chosen in accordance with the meaning of the word and its function in the sentence (Azzam, 1990; Abu-Rabia, 1997a, 1997b). In their absence, meaning is understood by context (Hazoury \& Oweine, 2010).

Additionally, the presence or absence of short vowels determines orthographic depth (Frost, 1998): when a text is vowelled (accompanied by vowels), the orthography is considered transparent and reading is based mainly on sublexical processes. When the text is unvowelled, the orthography is considered deep because the words are lacking in phonological information, making comprehension dependent on lexical processes (Frost, 1998; Katz \& Feldman, 1983). Certain words, however, become homographic (Abu-Rabia, 2001).

Children first learn to read transparent texts; they begin to use deeper orthography in the fourth grade or so (Abu-Ahmad et al., 2014). 
Three major characteristics influence the extent of orthographic transparency and contribute to its complexity:

1) The presence of auditory information that relates to pairs of characters that have similar phonology and are based on the same part of the vocal system (for example, س-ص ، ط-ت [s-ṣ; t-t]: one pronounced at a deep level and the other at a transparent level);

2) The fact that twenty-two of the twenty-eight characters are written in four different ways, depending on their position within the word;

3) The existence of sounds that are written but not pronounced in certain cases, along with others that are pronounced but not written in certain cases (e.g., the character alifin the word "هذ" [hāda], which is pronounced "hāda" but written as "hada".

Characteristics such as these abet inconsistency in the grapheme-to-phoneme conversion on which young children rely in the reading process before they master larger morphological units for automatic reading (Saiegh-Haddad \& Henkin-Roitfarb, 2014).

An orthographic system is one's understanding of the writing conventions of the language and of correct and incorrect words (Abu-Rabia, 1995). Arabic is a phonological-consonantal sign system that is written by means of a twenty-eight-character set to which diacritics are added (Abu-Rabia, 1997a, 1997b; Azzam, 1990). This system is highly complex, written from right to left, and representative of the set of sounds. Therefore, it is strongly phonetic.

As for the morphological system, most Arabic words are built by derivation from roots and combine meaning, represented by the roots, and lexical and syntactic categories, represented by patterns. Even though most roots are composed of three consonants (Abu-Rabia, 2001) that may abet some morphological transformation, these transformations are rarely linear. They tend to fracture the phonological and orthographic identity of the words and weaken their morphological transparency (Asadi et al., 2017).

Asaad and Eviatar (2014) find it useful to compare the processes of acquiring Arabic and of Hebrew due to patterns of similarity and dissimilarity that exist between the languages. Both languages are Semitic and have root-based morphology in which most words are derived by assimilating a root into a morpho-phonological word pattern.

The orthographies of both languages are A-B-C-D. The characters represent consonants and several long vowels; short vowels, in contrast, are represented by diacritics. Both orthographies allow two possible ways of spelling: with diacritics and without. When diacritics are used, the phonological form of the word is fully represented and the orthography is considered transparent. Non-diacritical spelling, in contrast, has several homographs, the phonological form of words is represented incorrectly, and the orthography is considered deep.

Another conspicuous difference is the visual complexity of the orthographies. Eviatar and Ibrahim (2004) showed that it takes longer to identify characters in Arabic than it does in Hebrew or in English. 
Abu-Rabia (2002) looked into proficiencies in reading, phonological processing, orthographic processing, performative memory, and spelling in Arabic, Hebrew, and English writing among native speakers of Arabic. They discovered that many proficiencies in the first language correlate strongly with spelling in English. They also found unique orthographic challenges in both Arabic and Hebrew. Despite the difference between the two types of writing, each graphic sign has vocalization and the orthography is considered "shallow" or "transparent", i.e., exhibiting a direct relation between grapheme and phoneme. When the opposite situation prevails-when diacritics are not used or full spelling is not usedthe orthography is considered "deep" (Abu-Rabia, Share, \& Mansour, 2003).

Abu-Rabia (1995) investigated the effect of vowels on reading accuracy among eight eight-year-old readers, some weak and others skilled. They found that vowelling improved their reading accuracy in general and their reading of words in their context particularly.

Children exposed to both forms of Arabic function bilingually because they have a higher level of phonological awareness than do Hebrew-speaking peers. By implication, one may expect them to show progress in gaining reading proficiency. In fact, however, they acquire reading skill in Arabic more slowly than do Hebrew speakers in Hebrew.

In a study conducted among first-graders, the children were given examinations that tested their phonological awareness and their vocabulary with texts tailored to their level. The correlations between the meta-linguistic indicators and reading showed that the level of difficulty in phonological awareness and reading is higher among Arabic-speaking children than among Hebrew-speaking youngsters. One may also see that children read Arabic more slowly and make more mistakes than do children reading Hebrew, even when they demonstrate higher levels of phonological capabilities than monolingual Hebrew speakers do (Abu-Ahmad et al., 2014).

\section{Arabic and Its Diglossic Nature}

According to Hazoury and Oweine (2010), diglossia is "bilingualism"-a situation in which two different forms of speaking, one official and the other vernacular, coexist and are used in different contexts. The two forms are differentiated in contexts, usage, and manner of acquisition (Khateb, Nevat, \& Prior, 2014).

Arabic (al-'Arabiyya) belongs to the Semitic family of languages and has two main forms: a vernacular ('amiya), divided into many geographical dialects (Spoken Arabic Vernacular-SAV), and a literary or standard form (fușhâ) (Modern Standard Arabic-MSA). Standard Arabic is not only the written form of Arabic; it is also the main language used in news broadcasts, the media, and religious and political rituals. Considered prestigious and esteemed, it is perceived as a high-level language shared by the intelligentsia throughout the Arab world. SAV, in contrast, with its many variations, is the mother tongue of all Arabic speakers irrespective of their education and is usually acquired before MSA is learned in school. The development of education and the spread of electronic media in the Arab world have set in motion a fascinating encounter be- 
tween the two forms of the language. In recent decades, an educational spoken Arabic that integrates the abstract literary form of the language with various elements of the vernacular has begun to develop.

The linguistic relationship between SAV and MSA is not straightforward. The two languages are far apart in many respects: pronunciation, inflection, syntax, vocabulary, and semantics. These differences create a unique linguistic situation known as diglossia. Diglossia is a relatively uncommon socio-linguistic state in which the written and the spoken languages are so differentiated that one may treat the former almost as a foreign tongue (Eghbaria, Ibrahim, \& Leikin, 2014).

Arabic-speaking children are born into this double linguistic context (Ferguson, 1959). They speak the vernacular of their parents, siblings, and peers at home and in their residential surroundings. In school, they are first exposed to MSA in Arabic-language classes. The different code of the standard language is a perceived almost as a foreign tongue and entails literary proficiencies of reading and writing, grammatical knowledge, and linguistic accuracy. As the sole written code, Modern Standard Arabic is also the language of textbooks in all subjects. Outside the school environment, the two linguistic codes maintain a rather stable coexistence, complementing each other in various areas of social functioning. Thus, SAV is used for unofficial quotidian conversational functions, usually oral only. MSA, in contrast, is invoked for writing and official linguistic functions such as religious sermons, speeches, newscasts, and the like (Saiegh-Haddad, Levin, Hende, \& Ziv, 2011).

Eghbaria et al. (2014) found that the effect of the linguistic distance between MSA and SAV is almost always studied among schoolchildren and less so among preschoolers. This happens for two reasons: First, the formal and direct exposure to MSA coincides with the initial acquisition of reading and writing at the beginning of the child's studies in school. Until then, children are exposed to MSA mainly through stories or watching television programs, but this exposure is weaker both qualitatively and quantitatively. Second, the linguistic distance between the two forms of Arabic has a particularly strong effect on the acquisition of basic reading proficiency.

It is not by chance that children are less successful when they are asked to analyze the pronunciation of literary linguistic structures and compare it with those in vernacular Arabic (Saiegh-Haddad, 2003, 2004). The findings (albeit few) of semantic and metacognitive research confirm these data in most cases, allowing us to hypothesise that children whose mother tongue is Arabic treat MSA much as bilingual children do after they are exposed to both forms of Arabic (Ibrahim, 2009a; Ibrahim \& Aharon-Peretz, 2005). Accordingly, it has been proposed that Arabic diglossia has an adverse effect on the acquisition of basic reading proficiency (Ibrahim, Eviatar, \& Aharon-Peretz, 2007) and, in contrast, a positive effect (like bilingualism) on the development of metalinguistic proficiency (Eviatar \& Ibrahim, 2001).

In the past decade, Saiegh-Haddad et al. (2008) have tried to surmount the SAV-MSA gap by providing early exposure to MSA at home and in preschool 
and by applying a structured and systematic approach in both of these settings. They propose that structured intervention develops awareness of syllables, characters, and identification of sounds, and broadens vocabulary in early childhood. They also observe that SAV has an adverse effect on the development of reading. Because children speak SAV until preschool age, they find it difficult to construct phonological representations of MSA words in the early school grades (Saiegh-Haddad et al., 2011; Saiegh-Haddad, 2003, 2004, 2007). Similarly, the cognitive systems of both children and adolescents treat SAV and MSA as separate languages.

Asaad and Eviatar (2014) claim that the diglossic nature of Arabic may impede the process of grapheme-phoneme conversion in form as well. One reason for this is that graphemes may represent phonemes that are unknown in the vernacular of young pupils; another is the linguistic distance between the two forms of Arabic. Due to this distance, children cannot rely on their phonological representations of words in the vernacular, even though the written Arabic orthography is shallow or transparent. Accordingly, to acquire Arabic reading skills they must learn two systems-one linguistic and the other orthographic concurrently.

\section{MSA vs. SAV}

Two characteristics define the diglossic context. The first is the gulf between the standard language and the way it is spoken. The second is that the two forms are complementary in the social functioning of two separate systems that are implemented by two codes that, while totally distinct, are linguistically linked.

Arabic is a typical case of diglossia. Modern Standard Arabic (MSA) is the language universally used for writing and other official purposes, such as speeches and religious rituals. It accommodates a broad spectrum of spoken dialects (Spoken Arabic Vernaculars-SAVs) that are used for daily conversation. Even though all SAVs are related to MSA, they are distinct from each other and maintain a perceptible distance from MSA in phonological, formal-syntactic, lexical, and semantic terms (Saiegh-Haddad, 2005).

The linguistic distance between MSA and SAV is evident in phonology, manifested in the composition of the phonemic stock and the syllabic structure of the two languages, the written and the vernacular. MSA has twenty-eight consonantal sounds and six vowels-three long and three short. In SAV, contrastingly, there is usually a complex vowel system but few consonants. This means that when they begin to learn to read, learners need to cope with a new system of consonantal sounds with which they are unfamiliar from their experience with the vernacular.

Despite its potential impact on the acquisition of basic reading proficiency, this diglossia did not begin to attract attention until recently. Several studies have shown that early exposure to MSA by reading stories led to an improvement in linguistic literacy and reading comprehension (Abu-Rabia, 2000; Feitelson, Goldstein, Iraqi, \& Share, 1993).

Saiegh-Haddad $(2003,2004)$ investigated the effect of the MSA/SAV linguistic 
distance on the acquisition of basic derivatives associated with reading. She examined the ascending order (from basic capabilities to more complex ones), asked whether linguistic structures that are far from each other in diglossia disrupt the acquisition of basic reading processes in MSA, and related to the effect of the phonological distance of SAV from MSA in attaining phonemic awareness and accuracy in encoding words. Examining preschool and first-grade children who are native speakers of the local Palestinian dialect of SAV in northern Israel, she discovered that the children found the phonemes of MSA more complicated to isolate and encode. It was also found that MSA phonemes are much harder to cope with when they are assimilated into MSA syllabic structures.

In another study, Saiegh-Haddad (2004) examined the effect of the lexical and phonemic distance of SAV from MSA on phonological analysis among children. Here she discovered that preschool children find words in MSA much harder to analyze than they do SAV words or dummy words, and that MSA phonemes are much harder to encode when they are assimilated into MSA words.

These insights reinforce the hypothesis that linguistic distance impedes the attainment of basic reading processes in diglossia, foremost due to two singular characteristics of Arabic: the transparent orthography of the vowelled language and the diglossic nature of Arabic. Even though vowelled Arabic is considered a "transparent" orthography that maintains regular and consistent relations with phonological representation, the diglossic nature of the language makes these relations less transparent. The reason lies in the orthography, which encodes phonological structures of MSA that are not included in children's experience with the vernacular. Under these circumstances, reading may be disrupted by unfamiliar phonological structures that do not exist in the SAV that the children know (Saiegh-Haddad, 2005).

Literacy skills and phonological awareness usually evolve intuitively as a function of the child's exposure to the language. This, however, does not occur in diglossic Arabic. The linguistic distance between the spoken word and the written word is manifested in various linguistic structures including morphology, phonology, and vocabulary. In terms of phonological structure, MSA and SAV are differentiated in their phonemic repertoires. On the one hand, SAV accommodates phonemes that exist in its vocabulary alone and are not represented in MSA orthography (an example is the phoneme $[\mathrm{q}]$, which appears in several versions, as in the word قلب [qalb] = heart]). On the other hand, some diglossic phonemes exist only in the MSA stock (e.g., the phoneme ث [tawr] = bull) (Saiegh-Haddad et al., 2011).

Unlike other languages, formal exposure to MSA takes place only at the onset of formal studies in school (Hudson, 2002). For this reason, coupled with insufficient exposure to MSA at home, MSA is considered a second language. When children begin to learn it in first grade, their shortcomings in phonemic repertoire and phonological awareness affect their phonological processing and, in turn, their acquisition of reading proficiency (Abu-Rabia, 2000). Saiegh-Haddad $(2003,2004,2007)$ shows clearly that Arab children in preschool and first grade 
find it immensely difficult to deconstruct MSA structures into phonemes. Furthermore, the phonological distance between the two types of Arabic affects subsequent decoding skills among first- and second-graders, who struggle to decode words that have phonemic and syllabic structures unique to MSA, resulting in a high rate of decoding errors in words composed of phonemes and syllabic structures that occur in SAV (Saiegh-Haddad, 2003).

The effect of phonological training on reading ability has been investigated in many studies, with reference to several subskills at the levels of different sound units. These works demonstrate the contribution of phonemic training to reading and spelling acquisition among skilled and unskilled readers (Bradley \& Bryant, 1985; Fox \& Ruth, 1984; Cunningham, 1990; Lundberg, Frost, \& Petersen, 1988; Schneider, Kuspert, Roth, Vise, \& Marx, 1997; Treiman \& Baron, 1983). Due to the errors in the phonological-awareness skills of children at the onset of their school years and the implications of these errors for the reading-acquisition process in the case of diglossic Arabic, it has been recommended that teaching of reading should include explicit, structured, and systematic training in phonological awareness (Makhoul, 2017).

MSA is the authentic version of classical Arabic and differs from the spoken dialects of the language in lexical items, phonology, morphology, and syntax. Children rarely use MSA until they begin to attend school; therefore, its acquisition is considered that of a second language (Ayari, 1996; Saiegh-Haddad, 2005, 2007). Accordingly, Arabic has the exceptional property of possessing two forms of one basic language. Children see one of these forms a verbal medium and regard the other form mainly as an educational tool and a rule-bound written medium.

Saiegh-Haddad (2007) claimed that the difference between SAV and MSA disrupts the construction of the phonological representations of MSA. Given that this may lead to less reliance on such representations to support the acquisition of literary proficiency, alternative processes to identify words should be used. Saiegh-Haddad (2005) found that among first-graders, too, phonological awareness is only indirectly associated with reading, in contrast to pupils in higher grades, whose awareness is manifested directly. Focusing on salient orthographic properties may be a more important strategy for study than centering on the grapheme-phoneme relationship (Mahfoudi, Everatt, \& Elbeheri, 2011).

\section{Early Exposure to MSA and the Acquisition of Arabic}

Although far-reaching exposure to MSA begins when formal education and teaching of reading start in first grade, it is a common error to think that children are exposed only to SAV until then and encounter diglossia only when they reach school. Arabic-speaking children are born into this dual linguistic context and their language ability evolves amid this hybrid linguistic reality. While surrounded mainly by vernacular Arabic, they are exposed to the standard language as well: They hear their parents praying in MSA and see their siblings doing their homework and prepping for exams largely in MSA. They watch television shows and series dubbed in MSA and, if their parents are literate and appreciative of 
the importance of developing their children's literacy skills, they are told stories in MSA.

In oral discussions that they hold after they read texts, watch television shows, or take an exam, children use SAV, especially in its phonological and morpho-syntactic respects. Just the same, they also insert some words from MSA. A mixed code of this kind, combining the lexicon of standard Arabic with the phonology and the morpho-syntax of the vernacular, is typical of literacy-based speech in Arabic, particularly when words in MSA have no parallel in SAV.

MSA is a predominantly uniform code (Holes, 2004). SAV, in contrast, is largely regional, manifested in dialects that vary among countries, cities, and villages. Despite the large linguistic differences among the dialects, all are structurally related to standard Arabic. However, linguistic analysis of SAV and MSA consistently reveals differences in all aspects of the language, including the phonological, the morpho-syntactic, and the lexical-semantic.

In the linguistic distance that exists between SAV and MSA, a given Arabic linguistic structure may be identified as belonging to one of three categories: SAV only, MSA only, or both together. This typology may be applied to all areas of the language, particularly phonology. That is, Arabic phonemes may be vernacular-only, standard-only, or both. Spoken-only phonemes are used in a specific dialect but do not appear in the MSA phonemic stock. Standard-only phonemes are those that occur in modern Arabic but not in a given SAV. Both standard-only phonemes and vernacular-only phonemes have conventional characters by which they are represented in Arabic orthography. Vernacular-only phonemes, in contrast, have no parallel characters in the Arabic alphabet. Notably, the aforementioned categorization is unique to SAV and may vary in other categories. Just the same, all three categories appear in all versions (Maamouri, 1998).

The phonological distance between MSA and SAV suggests that standard phonemes cannot be familiar to children when they begin to acquire reading proficiency in first grade. Accordingly, to gain an initial mastery of reading, youngsters may have to learn not only the orthographic representations of these phonemes but their phonological representations as well. Three factors may make this a complex task: 1) To acquire standard phonemes (such as ض-ش-ذ [d]-š-d]]), learners must construct new phonetic categories that do not exist in young children's phonological systems; 2) Standard phoneme types are identified as "heavy" phonemes that are more strongly accented than other phonemes

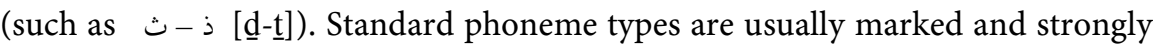
resemble other unmarked phonemes in the system. 3) Both types of phonemes, vernacular and standard, have distinct characters that represent them in the Arabic alphabet. Consequently, inaccurate phonological representation of standard phonemes may render children unable to distinguish between standard and vernacular ones and make it hard for them to associate the various phonemes with the characters that represent them. 
Children who speak Arabic as their native language may find phonological coding of standard words in long-term memory difficult and may encounter problems in accuracy and organizing words into categories. This confusion disrupts phonological analysis even in tasks that do not require phonological representation. This finding has crucial implications for the acquisition of reading proficiency in Arabic and for the ways this proficiency is imparted. The results show that the strictly limited and largely passive natural exposure of Arabic-speaking children to the literary language does not suffice to enable them to construct high-quality phonological representations for words in MSA. The construction of stable phonological representations improves the learning of words and facilitates the acquisition of reading proficiency (Perfetti, 2007).

The creation of high-quality phonological representations generally, and for cognates particularly, should help to make children aware of the lexical relationship of cognate words and allow them to utilise their lexical knowledge in SAV to develop literacy in MSA (Saiegh-Haddad et al., 2011; Ferguson, 1959).

\section{Research Questions}

1) How does Arabic diglossia affect fourth-grade pupils' syntactic ability in MSA?

2) Is there a performative difference between regular readers and struggling readers in MSA syntactic ability?

\section{Research Hypotheses}

1) Arabic diglossia diminishes fourth-grade pupils' syntactic ability in MSA.

2) The syntactic performance of regular readers is superior to that of struggling readers.

\section{Method}

\section{Participants}

The research population comprised sixty-three fourth-grade pupils who attend a primary school in central Israel. Twenty-six of them were boys and thirty-seven were girls; their average age was 9 - 10.

The participants were divided into two groups: one of regular readers and the other of struggling readers. The regular and the struggling readers were screened according to their performance on Arabic-language tests of the Israel Ministry of Education. Pupils who scored in the $0-60$ range were placed in the group of struggling readers; those scoring 85 - 100 were grouped as regular.

The participants had spent their entire lives in the same geographical region, within the boundaries of a regional-council jurisdiction in central Israel, and spoke the same local dialect. All were of average socioeconomic status. Those chosen were in good health and had no physical, developmental, behavioral, or cognitive disorders. They took various subjects in school, including seven weekly hours in their mother tongue (Arabic).

Tools

Three examinations were composed especially for the study: 
1) In the first examination, participants were asked to translate twenty sentences from SAV into MSA. Examples follow:

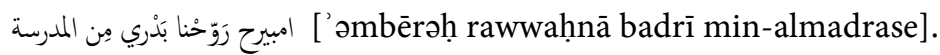

[ruhə̣t 'azūr sittī wā-salləm 'alēhā].

(See Appendix 1, p. 27)

2) The second examination was a cloze comprising twenty sentences in MSA, each missing a word. The pupils were asked to complete the sentence by filling in the missing word. Examples follow:

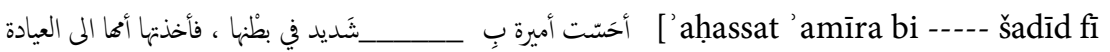
baṭnihā, fa' axaḍathā 'ummahā 'ilā-al iyāda].

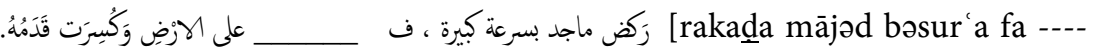
'alā-al' ardi wakusirat qadmhu].

(See Appendix 2, p. 28).

3) The third examination tested oral expression. The pupils were shown eight pictures and were asked to describe their contents orally

(See Appendix 3, p. 29).

\section{Procedure}

The first two examinations were given to each group collectively; the third was administered to each pupil individually. In the individual exam and the oralexpression exam, each pupil's performance was recorded in order to prevent loss of details. Each group was given forty-five minutes to take the collective examinations; each pupil was given ten minutes to take the individual exam.

The pupils received instructions before the examinations were handed out. The first two exams were administered collectively and did not have to be checked individually.

In the first exam, they were instructed: "Here are some sentences in spoken Arabic. Please write them in standard Arabic".

In the second: "Here are some sentences in which a word is missing. Please write out the missing word and complete the sentence".

In the third: "Describe what you see in the picture that's in front of you". Only this exam was given individually and recorded.

\section{Results}

After the two groups of fourth-graders-regular readers and struggling readers-took the three examinations, their syntactical errors were mapped. For each exam, a frequency table that juxtaposed the two groups' errors was constructed. Afterwards, means and standard deviations of syntax-related statements for both groups together were calculated. Since none of the variables was normal-distributed and the groups were not large, a Mann-Whitney non-parametric test was carried out to make the groups comparable. Finally, the differences among the average syntactical statements on each exam were checked and a $t$-test was performed to examine mean differences between the groups.

The Results section is divided into two levels of analysis: quantitative-statistical and qualitative (Table 1 ). 
Table 1. Frequency of gender and group.

\begin{tabular}{ccc}
\hline Gender & Frequency & $\%$ \\
\hline Boys & 26 & 41.3 \\
Girls & 37 & 58.7 \\
Group & & \\
Regular & 31 & 49.2 \\
Struggling & 32 & 50.8 \\
Total & 63 & 100.0 \\
\hline
\end{tabular}

58.7 percent of the participants were girls; 41.3 percent were boys.

50.8 percent belonged to the struggling group and 49.2 percent to the regular group.

Below are the syntax errors that were found on each exam separately:

Examination 1

1) Omission of connectives, particularly the word “" ['an]

2) Misuse of prepositions.

3) Deficient sentences.

4) Verb-conjugation errors.

Examination 2

1) Misuse of prepositions.

2) Deficient sentences.

3) Verb-conjugation errors.

Examination 3

1) Misuse of prepositions.

2) Deficient sentences.

3) Verb-conjugation errors (Table 2 and Table 3 ).

As stated, since none of the variables was normal-distributed (all were distributed asymmetrically to the right) and neither group was large (around thirty members in each), a Mann-Whitney non-parametric test was carried out in order to make the groups of regular and struggling pupils comparable in terms of syntactic elements. The tests found significant differences between the groups in only one syntactic element: $\mathrm{MW}-\mathrm{U}=286.5, p=0.002)$. In Examination 1 -misuse of prepositions-the regular group had a higher mean of misuse (1.9 among regular pupils as against 1.22 among struggling pupils).

Now we examine the mean differences among syntactic elements on each examination (Table 4).

Table 5 presents the results of an examination of means on the three examinations between the groups (normal or near-normal distribution of scores) via $t$-tests. Each group's mean is condensed separately.

No significant differences in means on the examinations were found between regular and struggling students in respect of syntactic elements. Both groups made similar numbers of syntax errors. 
Table 2. Frequency of syntax errors-both groups together.

\begin{tabular}{|c|c|c|}
\hline Examination 1 & Frequency & $\%$ \\
\hline \multicolumn{3}{|c|}{ Omission of connectives } \\
\hline 0 & 28 & 44.4 \\
\hline 1 & 22 & 34.9 \\
\hline 2 & 11 & 17.5 \\
\hline 3 & 1 & 1.6 \\
\hline 4 & 1 & 1.6 \\
\hline \multicolumn{3}{|c|}{ Misuse of prepositions } \\
\hline 0 & 8 & 12.7 \\
\hline 1 & 22 & 34.9 \\
\hline 2 & 23 & 36.5 \\
\hline 3 & 10 & 15.9 \\
\hline \multicolumn{3}{|l|}{ Deficient sentences } \\
\hline 0 & 25 & 39.7 \\
\hline 1 & 17 & 27.0 \\
\hline 2 & 9 & 14.3 \\
\hline 3 & 7 & 11.1 \\
\hline 4 & 4 & 6.3 \\
\hline 6 & 1 & 1.6 \\
\hline \multicolumn{3}{|c|}{ Verb-conjugation errors } \\
\hline 0 & 53 & 84.1 \\
\hline 1 & 10 & 15.9 \\
\hline Total & 63 & 100.0 \\
\hline Examination 2 & Frequency & $\%$ \\
\hline \multicolumn{3}{|c|}{ Verb-conjugation errors } \\
\hline 0 & 26 & 41.3 \\
\hline 1 & 36 & 57.1 \\
\hline 2 & 1 & 1.6 \\
\hline Total & 63 & 100.0 \\
\hline Examination 3 & Frequency & $\%$ \\
\hline \multicolumn{3}{|c|}{ Misuse of prepositions } \\
\hline 0 & 29 & 46.0 \\
\hline 1 & 25 & 39.7 \\
\hline
\end{tabular}




\section{Continued}

\begin{tabular}{|c|c|c|}
\hline 2 & 6 & 9.5 \\
\hline 3 & 3 & 4.8 \\
\hline \multicolumn{3}{|c|}{ Deficient sentences } \\
\hline 0 & 21 & 33.3 \\
\hline 1 & 18 & 28.6 \\
\hline 2 & 13 & 20.6 \\
\hline 3 & 7 & 11.1 \\
\hline 4 & 2 & 3.2 \\
\hline 5 & 2 & 3.2 \\
\hline \multicolumn{3}{|c|}{ Verb-conjugation errors } \\
\hline 0 & 36 & 57.1 \\
\hline 1 & 20 & 31.7 \\
\hline 2 & 4 & 6.3 \\
\hline 3 & 3 & 4.8 \\
\hline Total & 63 & 100.0 \\
\hline
\end{tabular}

Table 3. Means and standard deviations of syntactic statements-both groups together.

\begin{tabular}{cccc}
\hline & Mean & SD & N \\
\hline Examination 1 & & & \\
Omission of connectives & 0.81 & 0.895 & 63 \\
Misuse of prepositions & 1.56 & 0.912 & 63 \\
Deficient sentences & 1.24 & 1.388 & 63 \\
Verb-conjugation errors & 0.16 & 0.368 & 63 \\
Examination 2 & & & 63 \\
Verb-conjugation errors & 0.60 & 0.525 & 63 \\
Examination 3 & & & 63 \\
Misuse of prepositions & 0.73 & 0.827 & 63 \\
Deficient sentences & 1.32 & 1.305 & 63 \\
Verb-conjugation errors & 0.59 & 0.816 & 63
\end{tabular}

Table 4. Mean syntactic statements on each examination.

\begin{tabular}{lccc}
\hline & Mean & SD & N \\
\hline Mean, Examination 1: syntactic elements & 0.941 & 0.573 & 63 \\
Mean, Examination 2: syntactic elements & 0.603 & 0.525 & 63 \\
Mean, Examination 3: syntactic elements & 0.878 & 0.654 & 63 \\
\hline
\end{tabular}


Table 5. Means of typical and poor readers' results on the 3 examinations.

\begin{tabular}{ccccc}
\hline Observations & SDs & Means & \multicolumn{2}{c}{ Readers and Syntax } \\
\hline 31 & 0.532 & 0.984 & Typical & Mean of exam-1 syntax \\
32 & 0.615 & 0.898 & Poor & \\
31 & 0.564 & 0.581 & Typical & exam-2 syntax \\
32 & 0.492 & 0.625 & Poor & \\
31 & 0.377 & 0.763 & Typical & exam-3 syntax \\
32 & 0.831 & 0.989 & Poor & \\
\hline
\end{tabular}

The mean syntax errors committed by the two groups on the three examinations are described in Figure 1.

\section{Qualitative Analysis}

The purpose of this study is to examine the effect of diglossia on syntactic ability and sentence structure. The findings show that diglossia manifests in fourth-graders' performance in four respects: omission of connectives, misuse of prepositions, verb-conjugation errors, and numerous deficient sentences.

Each group of pupils, regular and struggling, made the same number of errors.

Omission of connectives errors-When pupils found it difficult to translate sentences from SAV into MSA (Examination 1), they translated the vernacular sentence الطريقة لا أحب تحكي معي بهذه into [là 'uhibb təḥkī ma'ī b-hādīitțariqa].

In this translation, the connective "i", ['an] by which the full meaning is conveyed, was omitted. The pupils made this omission because أن is not used in SAV, resulting in the following wording is: بحش ان تحكي معي بهاي الطريقة [baḥibbiš toḥkī ma'i b-hāyə-țariqā]. Thus, the connective was omitted from the translation due to the influence of the vernacular.

In another example, the sentence اليوم بدي أنام بكّر مشان اصحى بكرا بكّير ['olyōm biddi

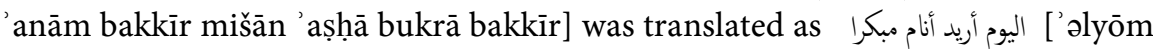
'urīd 'anām mubakkiran].

Again, the connective "ن", ['an] which completes the meaning, is omitted because انام مبكرا اليوم بدي أن ['alyōm biddi 'an 'anām mubakkiran] is not said in SAV.

Misuse of prepositions was conspicuous among both groups of pupils. The

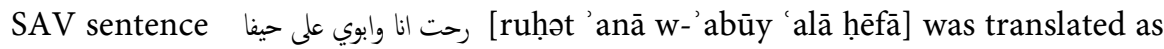

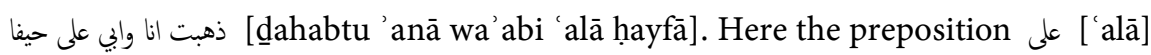
was misused; its proper form is الى حيفا ['ilā hayfā].

When they took Examination 3, too-the oral exam-pupils in both groups made mistakes of this kind. Describing a picture, for example, they said القط يركض ['alqatțu yarkudu warā'-alfa' ar wal'imra'a tandur 'alayhəm, walwalad -əlkabīr yandur 'alayhəm]. The phrasing belongs to the vernacular (تطلّم عليم [titțalla' 'alēhum]); the proper wording is تنظر اليهم, [tandur 'alayhəm] and not ['alayhəm]. 


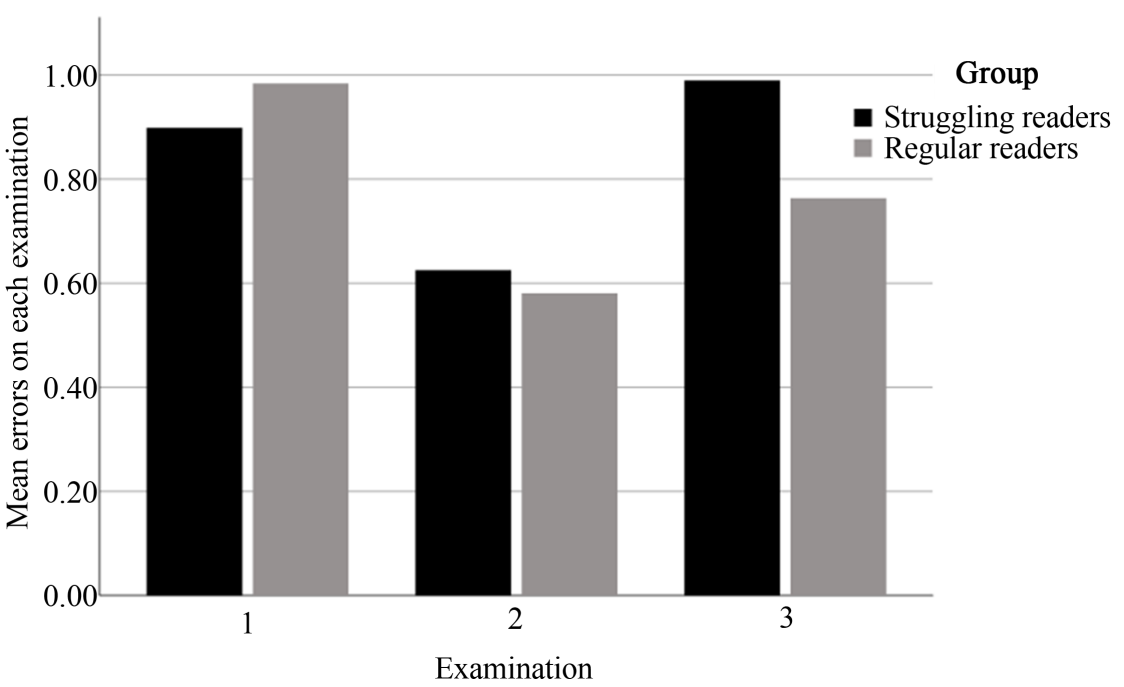

Figure 1. The mean syntax errors committed by the two groups on the three examinations.

Another recurrent example of misuse of prepositions was ارى ولد يجلس تحت الشجرة ['arā walad yajlis taḥt-aššajara wa' awlād yal'abūna fi-lkura]. Here, too, the expression في الكرة [fi-lkura] was harvested from the vernacular; the correct usage is الولاد يلعبون بالكرة ['al'awlād yal'abūna bilkurati].

On its face, the percentage of errors was higher among the group of regular pupils than among the group of the struggling pupils. The reason is that the regular pupils answered all questions, whereas the struggling pupils did not. Consequently, the struggling pupils had a lower percentage of errors because they left questions unanswered.

In another example, the sentence محمود من الصف الخامس جب ع المعلمة [mahmūd min-așṣaff-ilxāmis bā sabb 'a-əlmə'allime] was translated as

[maḥmūd min-aș̣̣aff-ilxāmis jīm šatam 'alā-lmə'allime]. Here the pupils produced a close, literal word-for-word translation, not thinking that words could be forgone without changing the meaning. The correct translation would have been محمود من الصف الخامس جت شتم المعلمة [mahmūd min-așṣaff-ilxāmis jīm šatam-əlmə allime].

Deficient sentences accounted for a large percent of the pupils' answers: 60.3 percent of the pupils (38 of 63) in Examination 1 and 66.7 (42 pupils) in Examination 3.

The errors are rooted in the effect of diglossia. Here are several examples:

[talabat-olmu 'allima min 'ibnihā 'așșagīir ' an lā ya' kul-əssakākər laylan likay lā ta' tī-ssūsa 'alā 'asnānihi].

[نقطع فستان رشا الجديد واصبحت تبكي بصوت عالي ['inqața'a fustān rašā-aljadīd wa'aṣbaḥat tabkī bișawtin 'ālì].

اقتزب العيد ونخن لسنا مشتريين ملابس ' ['iqtarab-al 'īd wanaḥnu lasnā muštariyin malābəs].

The fourth type of syntactic element that stood out in the pupils' answers was verb-conjugation errors. Most such errors occurred on Examination 2 and in- 
volved the conjugation of a singular verb in the plural:

وقنوا التلاميذ بانظطام في ساحة المدرسة.

[ينظمون التلاميذ بانتطام في ساحة المدرسة.

olmadrasa].

يلعبوا التلاميذ بانتظام في ساحة المدرسة. [yal'abū-ttalāmid bīntị̣ām fī sāḥat-olmadrasa].

The effect of diglossia is strongly visible in these examples, since in SAV it is customary to say أكوا الخولاد ، ناموا الخولاد ـ شربوا الاولاد ['akalū-l'awlād, nāmū-l'awlād,

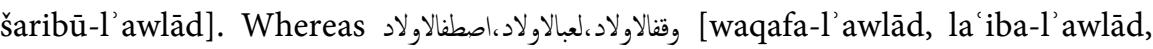
'iștaffa-l' awlād] in the singular as opposed to the plural in the vernacular-is the customary wording in MSA.

In sum, the phenomenon of diglossia in Arabic has a powerful and conspicuous effect on those who acquire the language. The errors among both groups focused on these issues: omission of connectives, misuse of prepositions, deficient sentences, and verb-conjugation errors. The results obtained in the three examinations indicate identical performance among both groups of pupils, finding no significant differences between them.

The findings imply that the research hypotheses are confirmed. Arabic diglossia affects pupils' syntactic ability to compose sentences in the standard language. The second hypothesis, concerning the quality of the pupils' performance, is also confirmed, notwithstanding a minor difference between the groups.

\section{Discussion}

The main results of the study follow:

1) The diglossia that is typical of Arabic affects syntactic proficiency in Modern Standard Arabic among fourth-grade pupils.

2) The errors committed by members of both groups-regular and struggling - in omission of connectives, misuse of prepositions, numerous deficient sentences, and verb-conjugation errors.

3) No significant differences were found in the average test scores between the group of regular readers and the group of struggling readers in the syntactic elements that were examined.

These results raise the question of why diglossia has such a powerful impact in Arabic. After all, there is some distance between the vernacular and the standard in Hebrew and in English as well. Below I wish to explain why the gap and the effects are so large in Arabic.

\section{The Similarity of SAV and MSA in Terms of Context and Meaning}

Saiegh-Haddad \& Schiff (2017) writes: "All vernacular varieties of Arabic are related to standard Arabic and share the same phonological, morphological, and verbal structure. Furthermore, it is found that 21.2 percent of words in the child's vernacular lexicon are identical, i.e., words that have the same lexico-phonological form in vernacular and standard Arabic, as in daftar (notebook) and nam (old)".

The results of the study show that a sizable proportion of words recurs in both 
standard and everyday Arabic. In the sentence يوم الوحد الجاي عنا فطور جاعي بالمدرسة [yōm-əl' aḥad-əljāy 'annā fṭūr jamā 'ì bīlmadrasa], for example, five of the seven

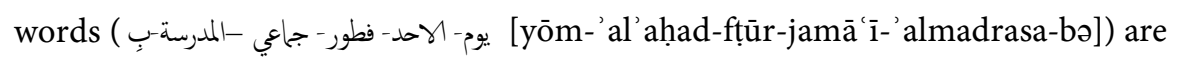
common to both languages. For additional examples, see Appendix 1, p. 27.

\section{Contribution of Environment and Parents}

Children's exposure to MSA is very limited and largely passive, leaving them unable to construct high-quality phonological representations of MSA words. It is by constructing stable phonological representations that one can learn words and acquire reading proficiency (Perfetti, 2007). The discourse among family members at home and among others in the daily surroundings takes place entirely in the vernacular. Parents at home do not give their young children adequate exposure to the standard language and the dialogue in many television programs takes place in the vernacular.

Feitelson et al. (1993) noted that exposing preschool children to MSA by reading them stories has a favorable effect on their proficiency in MSA. By implication, it is important for parents to expose their children to MSA at home. The absence of this exposure and the exclusive use of the vernacular in daily discourse explain children's lack of proficiency in the basic skills of their native language.

Only children fortunate enough to have well-educated parents who understand the importance of exposing them to the language of literacy are privileged to hear stories in MSA and to acquire linguistic skills in it. An especially interesting finding in this context has to do with the fact that kindergarten children already acquire MSA to an extent that allows them consistently to re-tell a story that is read to them in their mother tongue and to demonstrate excellent comprehension of MSA and of many literary words. Accordingly, despite the absence of formal education in Modern Standard Arabic at kindergarten age, children clearly have enough opportunities to become fluent in MSA (Eghbaria et al., 2014). This finding demonstrates the powerful potential of a supportive and enriching early-childhood environment in mitigating the effect of diglossia on the acquisition of Standard Arabic.

\section{Dearth of Book-Reading}

In the age of technology, reading books is becoming less common. The importance of exposure to and reading of books is crucial because the literary language is a standard language that can enrich the reader's world beyond the vernacular. In our times, children are denied the acquisition of the standard language and the vernacular eventually becomes their established tongue. Furthermore, today's children are inadequately exposed to television programs that would enrich their proficiency in the standard language due to heightened occupation with electronic media, computers, smartphones, and tablets, in which, of course, they are hardly exposed to the standard tongue.

This deficiency is manifested in the difficulty in identifying standard phonemes, as evidenced in the results of the examinations that we administered. This finding is consistent with Saiegh-Haddad et al. (2011), who showed that 
standard phonemes are harder to identify than are vernacular ones. A shortage of phonological representations of standard words is also found-a difficulty that, in my opinion, traces to inadequate exposure to MSA.

\section{Language of Instruction in School}

The language of instruction in Arab schools today is SAV. Students learn most subjects-science, geography, math, and English, to name only a few-in this language. A schoolchild has no linguistic role model. Even classes held for the purpose of imparting MSA are taught in the vernacular by most if not all teachers. Consequently, pupils learn in a vernacular linguistic environment and are not exposed to the standard language. In this state of affairs, one cannot expect pupils to master MSA and use it to write and express themselves adequately.

The situation makes one question the training of Arab schoolteachers. In the field of teacher training, there is a difference between primary and post-primary schools. In the latter, teachers are on a higher level and have a stronger academic education. Despite recommendations to elevate the academic standards of Arab teacher-training colleges and to toughen the admission requirements, the curricular content and teacher-training methods of these schools fall short of what is needed (Al-Haj, 1994).

This important point attests to the poor training of primary school teachers relative to those at the post-primary level. The primary school is the foundation for the rest of children's lives; it is during these years that they acquire the fundamentals of language. Can it be that we would not invest in a teacher who trains the next generation at so important an age for language acquisition? If so, how can one expect children to obtain a strong foundation if they lack role models?

The diglossic situation that prevails in Arabic does not exist to the same extent in other languages, e.g., Hebrew and English, in which the vernacular is the written language. Due to the diglossic nature of Arabic, its readers, unlike readers of English or Hebrew, do not acquire sufficient vocabulary by hearing to decode words in the written language. Thus, as a rule, beginning readers in Arabic have no phonological representation of the words that they read (Saiegh-Haddad \& Schiff, 2017). Instead, they have to discover the linguistic link between the two forms of the word and bridge the linguistic distance between them. It is a very onerous task if one recalls that phonological distance is based on distance in the formal and syntactic structure of the word. In addition, the phonological structure of almost all functional words and a large majority of common content words that children encounter in MSA is totally different from that in SAV, the language of the child's surroundings (Saiegh-Haddad, 2005).

\section{The Presence of Hebrew in Arab Pupils' Lives}

The official language in the country that we inhabit is Hebrew. As citizens, we have to learn this language at a very early age in order to facilitate our acclimation. Addressing himself to this key issue, Mar'i (2013) writes: "Hebrew has crowded out standard Arabic and has become a mediator of sorts between it and the vernacular. The decision-makers in this country have managed to turn the 
officiality of Arabic into an imagined officiality. Arabic pupils' fluency in the standard language is weakening. Therefore, the Ministry of Education should revise the criteria for the admission of teachers to the Arab education system, test their linguistic fitness, and invest more in teaching the language".

Young learners encounter Hebrew in kindergarten and school and soon make it part of their lives. They first encounter Hebrew and MSA in preschool and then in school. Their parents and older siblings speak Hebrew; so do their teachers. Thus, Hebrew evolves in them but MSA does not. Instead, MSA withers as the vernacular remains the language in which they speak and learn. In this state of affairs, it is no wonder that children miss out on study of the prestigious, standard form of Arabic.

To describe how powerfully Hebrew has entered Arabic, I conversed with some of my third-grade pupils and transcribed several sentences that they uttered:

1) امبيرح رحنا انا وعيلتي ع الكنيون ['ombērəḥ ruhnnā 'anā w'èltī 'a-lkənyun].

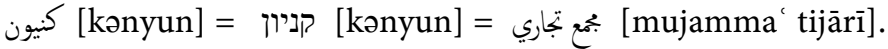

2) ['immī 'axdِdatnī 'ala kubbāt ḥulīm li'annī kuntə mrị̣a].

كوبات حوليم [kubbāt ḥulīm] = صاפת חולים [kupāt ḥulīm] = صندوق المرض [sundūqolmarda].

3) بده يعملوا بالحارة عنا مسحكِيكا [bidhum ya malū bəlḥ̄āa 'onna misḥakiyā].

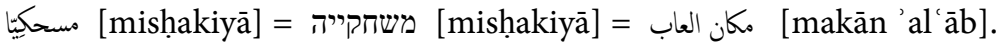

4) هاذ صوت سيارة الجليدا [hād ṣōt sayyārot-əlglīdā].

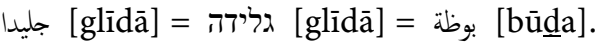

These and other examples show how pervasively Hebrew has influenced Arabs pupils' use of their language. In these cases, we encounter Hebrew alongside SAV and not alongside MSA.

\section{No Encouragement from the Education System}

A glance at the high schools raises an important point: a large share of the schools use Hebrew textbooks to teach scientific subjects. Thus, the education system does not encourage teaching in SAV, meaning that adolescents take matriculation exams in a language other than their native tongue.

Importantly, too, most institutes of higher education award bonuses for several matriculation subjects that are tested at the level of four or five study units. In my interviews with teachers and several high school students, I found that more youngsters prefer to be tested at the five-point level in subjects such as math, English, and physics, and to be tested at a lower level in Arabic, because the subjects listed first open more doors of opportunity to them, particularly in this age of technology.

They would rather be tested at five units in English and three units in Arabic than the other way around. Five units in Arabic will not allow them to take specialised university studies and enter a prestigious occupation. As the world advances and develops, matters are seen today in economic and technological terms. Many teachers whom I interviewed spoke in this manner. Even young 
students have a similar outlook. Aware of what is happening around them, they settle for the three-level matriculation exam in Arabic and prefer the five-unit level in other subjects, such as electronics, physics, and math. By comparison, only twenty of 168 high school students in a high school in central Israel took the matriculation exam in Arabic at the five-unit level-11.90 percent of all students who stood for matriculation.

This attitude captures the steep decline in the standing of MSA. Neither students nor teachers consider MSA a prestigious subject that should be learned and do not value in-depth study of matters associated with it, such as literature, syntax, written expression, and poetry. The picture that stands out is neglect of MSA instead of enrichment.

In sum, according to the findings of the study, the reasons for the heavy influence of diglossia in Arabic among fourth-graders are:

1) The similarity of the two languages-SAV and MSA;

2) The influence of the surroundings;

3) Scanty reading of books;

4) The language of instruction in Arab schools;

5) The presence of Hebrew in Arab pupils' lives;

6) No encouragement from the establishment and the education system.

\section{Educational Recommendations}

1) Parent-teacher encounters that include a discourse about the differences between vernacular Arabic and the standard language may do much for children. Such encounters may give them in-depth knowledge of the similarities/dissimilarities of the languages and expose them to examples from sentences in daily life, thus enhancing their proficiency in MSA.

2) The environment has a major role to play in exposing children to their mother tongue. Exposure to MSA should begin at a very early age. Parents should tell their children stories in MSA and encourage them to read books in MSA. This would enable them to serve their children as role models and direct the discourse at home, and the television shows that their children watch, toward enrichment in MSA.

3) Programs and contests that have the goal of reading books, with incentive prizes for the winners, should be held at the local and countrywide levels. In addition, class hours for study of MSA in Arab schools should be allocated and targets should be set in order to test the results of this study.

4) The education system and the decision-makers need to change their approach to the whole matter of admission requirements to teachers' colleges and should demand a high level of fluency in MSA on the admission tests. Similarly, the curriculum should reinforce and preserve MSA.

5) The attitude toward MSA in post-primary schools also needs to be revised. Teachers should understand that is their duty to reach out to their students in the matter of MSA, assimilate the language in them, and consider it a precious asset that should be safeguarded as an inseparable part of their culture.

\section{Limitations of the Study}


This is the first study that examined the direct implications of Arabic diglossia for syntactic proficiency in Modern Standard Arabic. As such, it took a small step down a long and winding road. Future research in this field should investigate the impact of this diglossia on a more representative sample and at different age levels. It should also address itself to differences between pupils of high socioeconomic status as against those of lower status in order to yield more comprehensive and representative results.

The findings of this study show how strongly diglossia affects syntactic proficiency in Arabic. They reinforce previous findings and enrich the research literature on this phenomenon from a different angle.

The discussion of the results of this study shows that the environment has a major influence on the acquisition of proficiency in Modern Standard Arabic and demonstrates how essential it is to revise teaching methods in order to encourage and reinforce proficiency in MSA among schoolchildren.

\section{Conflicts of Interest}

The authors declare no conflicts of interest regarding the publication of this paper.

\section{References}

Abu-Ahmad, H., Ibrahim, R., \& Share, D. L. (2014). Cognitive Predictors of Early Reading Ability in Arabic: A Longitudinal Study from Kindergarten to Grade 2. In E. Saiegh-Haddad, \& M. Joshi (Eds.), Handbook of Arabic Literacy (pp. 171-194). Springer. https://doi.org/10.1007/978-94-017-8545-7_8

Abu-Rabia, S. (1995). Reading in Arabic Orthography: Phonological, Syntactic, Working Memory Skills in Normally Achieving and Poor Arabic Readers. Reading Psychology: An International Quarterly, 16, 351-394. https://doi.org/10.1080/0270271950160401

Abu-Rabia, S. (1997a). Reading in Arabic Orthography: The Effect of Vowels and Context on Reading Accuracy of Poor and Skilled Native Arabic Readers in Reading Paragraphs, Sentences and Isolated Words. Journal of Psycholinguistic Research, 26, 465-482.

Abu-Rabia, S. (1997b). Reading in Arabic Orthography: The Effect of Vowels and Context on Reading Accuracy of Poor and Skilled Native Arabic Readers. Reading and Writing: An Interdisciplinary Journal, 9, 65-78.

Abu-Rabia, S. (2000). Effects of Exposure to Literary Arabic on Reading Comprehension in a Diglossic Situation. Reading and Writing: An Interdisciplinary Journal, 13, 147-157. https://doi.org/10.1023/A:1008133701024

Abu-Rabia, S. (2001). The Role of Vowels in Reading Semitic Scripts: Data from Arabic and Hebrew. Reading and Writing: An Interdisciplinary Journal, 14, 39-59. https://doi.org/10.1023/A:1008147606320

Abu-Rabia, S. (2002). Reading in a Root-Based Morphology Language: The Case of Arabic. Journal of Research in Reading, 25, 299-309. https://doi.org/10.1111/1467-9817.00177

Abu-Rabia, S., \& Awwad, J. (2004). Morphological Structures in Visual Word Recognition: The Case of Arabic. Journal of Research in Reading, 27, 321-336. https://doi.org/10.1111/j.1467-9817.2004.00235.x 
Abu-Rabia, S., Share, D., \& Mansour, M. (2003). Word Recognition and Basic Cognitive Processes among Reading Disabled and Normal Readers in the Arabic Language. Reading and Writing: An Interdisciplinary Journal, 16, 423-442. https://doi.org/10.1023/A:1024237415143

Al-Haj, M. (1994). The Arab Education System in Israel: Issues and Trends. Floersheimer Institute for Policy Studies (in Hebrew).

Asaad, H., \& Eviatar, Z. (2014). Learning to Read in Arabic: The Long and the Winding Road. Reading and Writing, 27, 649-664. https://doi.org/10.1007/s11145-013-9469-9

Asadi, I., Ibrahim, R., Khateb, A., \& Taha, H. (2017). How Do Different Cognitive and Linguistic Variables Contribute to Reading in Arabic? A Cross-Sectional Study from First to Sixth Grade. Reading and Writing, 30, 1835-1867. https://doi.org/10.1007/s11145-017-9755-z

Ayari, S. (1996). Diglossia and Illiteracy in the Arab World. Language, Culture and Curriculum, 9, 243-253. https://doi.org/10.1080/07908319609525233

Azzam, R. (1990). The Nature of Reading and Spelling Errors of Young Children: A Descriptive Study. Columbia University Press.

Bradley, L., \& Bryant, P. E. (1985). Rhyme and Reason in Reading and Spelling. University of Michigan Press. https://doi.org/10.3998/mpub.7194

Caravolas, M., Lervag, A., Defior, S., Malkova, G. S., \& Hulme, C. (2013). Different Patterns, but Equivalent Predictors, of Growth in Reading in Consistent and Inconsistent Orthographies. Psychological Science, 24, 1398-1407.

https://doi.org/10.1177/0956797612473122

Cunningham, A. E. (1990). Explicit versus Implicit Instruction in Phonemic Awareness. Journal of Experimental Child Psychology, 50, 429-444. https://doi.org/10.1016/0022-0965(90)90079-N

Eghbaria, H., Ibrahim, R., \& Leikin, M. (2014). The Influence of Diglossia in Arabic on Narrative Ability: Evidence from Analysis of the Linguistic and Narrative Structure of Discourse among Pre-School Children. Reading and Writing, 27, 733-747. https://doi.org/10.1007/s11145-013-9462-3

Ehri, L. C. (1998). Grapheme-Phoneme Knowledge Is Essential for Learning to Read Words in English. In J. L. Metsala, \& E. C. Ehri (Eds.), Word Recognition in Beginning Literacy (pp. 3-40). Erlbaum.

Eviatar, Z., \& Ibrahim, R. (2001). Bilingual Is as Bilingual Does: Metalinguistic Abilities of Arabic-Speaking Children. Applied Psycholinguistics, 21, 451-471. https://doi.org/10.1017/S0142716400004021

Eviatar, Z., \& Ibrahim, R. (2004). Morphological and Orthographic Effects on Hemispheric Processing of Nonwords: A Cross-Linguistic Comparison. Reading and Writing: An Interdisciplinary Journal, 17, 691-705. https://doi.org/10.1007/s11145-004-2659-8

Feitelson, D., Goldstein, Z., Iraqi, J., \& Share, D. L. (1993). Effects of Listening to Story Reading on Aspects of Literacy Acquisition in a Diglossic Situation. Reading Research Quarterly, 28, 71-79.

Ferguson, C. A. (1959). Diglossia. WORD, 15, 325-340. https://doi.org/10.1080/00437956.1959.11659702

Fox, B., \& Routh, D. K. (1984). Phonemic Analysis and Synthesis as Word Attack Skills: Revisited. Journal of Educational Psychology, 76, 1059-1064. https://doi.org/10.1037/0022-0663.76.6.1059

Frost, R. (1998). Toward a Story Phonological Theory of Visual Word Recognition: True 
Issues and False Trails. Psychological Bulletin, 123, 71-99.

https://doi.org/10.1037/0033-2909.123.1.71

Hazoury, K., \& Oweine, A. (2010). Towards a Sight List in Arabic. International Review of Education, 56, 457-478. https://doi.org/10.1007/s11159-010-9170-z

Herts, L. R., Ibrahim, R., \& Shibel, S. (2014). The Complex Nature of Text Reading Difficulties: The Case of Bilingual Children. Psychology, 5, 1911-1921.

https://doi.org/10.4236/psych.2014.516194

Holes, C. (2004). Modern Arabic: Structures, Functions, and Varieties. Georgetown University Press.

Hudson, A. (2002). Outline of a Theory of Diglossia. International Journal of the Sociology of Language, 157, 1-48. https://doi.org/10.1515/ijsl.2002.039

Ibrahim, R. (2009a). The Cognitive Basis of Diglossia in Arabic: Evidence from a Repetition Priming Study within and between Languages. Psychology Research and Behavior Management, 2, 93-105. https://doi.org/10.2147/PRBM.S5138

Ibrahim, R. (2009b). The Connection between Phonological Awareness and Reading among Arabic-Speaking children. Hebrew Psychology. http://www.hebpsy.net/articles.asp?id=1978

Ibrahim, R., \& Aharon-Peretz, J. (2005). Is Literary Arabic a Second Language for Native Arab Speakers? Evidence from a Semantic Priming Study. Journal of Psycholinguist Research, 34, 51-70. https://doi.org/10.1007/s10936-005-3631-8

Ibrahim, R., Eviatar, Z., \& Aharon-Peretz, J. (2007). Metalinguistic Awareness and Reading Performance: A Cross Language Comparison. Journal of Psycholinguistic Research, 36, 297-317. https://doi.org/10.1007/s10936-006-9046-3

Katz, L., \& Feldman, L. B. (1983). Relation between Pronunciation and Recognition of Printed Words in Deep and Shallow Orthographies. Journal of Experimental Psychology: Learning, Memory and Cognition, 9, 157-166.

https://doi.org/10.1037/0278-7393.9.1.157

Khateb, A., Nevat, M., \& Prior, A. (2014). When First Language Is Not First: A Functional Magnetic Resonance Imaging Investigation of the Neural Basis of Diglossia in Arabic. European Journal of Neuroscience, 40, 3387-3395. https://doi.org/10.1111/ejn.12673

Lundberg, I., Frost, J., \& Petersen, O. P. (1988). Effects of an Extensive Program for Stimulating Phonological Awareness in Preschool Children. Reading Research Quarterly, 23, 263-284.

Maamouri, M. (1998). Language Education and Human Development: Arabic Diglossia and Its Impact on the Quality of Education in the Arab Region. The Mediterraneam Development Forum. The World.

Mahfoudi, M., Everatt, J., \& Elbeheri, G. (2011). Introduction to the Special Issue on Literacy in Arabic. Reading and Writing: An Interdisciplinary Journal, 24, 1011-1018. https://doi.org/10.1007/s11145-011-9306-y

Makhoul, B. (2017). Moving beyond Phonological Awareness: The Role of Phonological Awareness Skills in Arabic Reading Development. Journal of Psycholinguistic Research, 46, 469-480. https://doi.org/10.1007/s10936-016-9447-x

Mar'i, A. (2013). Walla Beseder: A Linguistic Profile of the Arabs in Israel. Keter Books.

Perfetti, C. (2007). Reading Ability: Lexical Quality to Comprehension. Scientific Studies of Reading, 11, 357-383. https://doi.org/10.1080/10888430701530730

Plaut, D. C., McClelland, J. L., Siedenberg, M. S., \& Patterson, K. (1996). Understanding Normal and Impaired Word Reading: Computational Principles in Quasi-Regular Domains. Psychological Review, 103, 56-115. 
https://doi.org/10.1037/0033-295X.103.1.56

Saiegh-Haddad, E. (2003). Linguistic Distance and Initial Reading Acquisition: The Case of Arabic Diglossia. Applied Psycholinguistics, 24, 115-135. https://doi.org/10.1017/S0142716403000225

Saiegh-Haddad, E. (2004). The Impact of Phoneme and Lexical Distance on Phonological Analysis of Words and Pseudo Word in a Diglossic Context. Applied Psycholinguistics, 25, 495-512. https://doi.org/10.1017/s0142716404001249

Saiegh-Haddad, E. (2005). Correlates of Reading Fluency in Arabic: Diglossia and Orthographic Factors. Reading and Writing: An Interdisciplinary Journal, 18, 559-582. https://doi.org/10.1007/s11145-005-3180-4

Saiegh-Haddad, E. (2007). Linguistic Constraints on Children's Ability to Isolate Phonemes in Arabic. Applied Psycholinguistics, 28, 607-625. https://doi.org/10.1017/S0142716407070336

Saiegh-Haddad, E., \& Henkin-Roitfarb, R. (2014). The Structure of Arabic Language and Orthography. In E. Saiegh-Haddad, \& M. Joshi (Eds.), Handbook of Arabic Literacy: Insights and Perspectives (pp. 3-28). Springer. https://doi.org/10.1007/978-94-017-8545-7_1

Saiegh-Haddad, E., \& Schiff, R. (2017). When Diglossia Meets Dyslexia: The Effect of Diglossia on Voweled and Unvoweled Word Reading among Native Arabic-Speaking Dyslexic Children. Reading and Writing, 30, 1089-1113. https://doi.org/10.1007/s11145-016-9713-1

Saiegh-Haddad, E., Levien, I., Hende, N., \& Ziv, M. (2008). Early Literacy in Arabic: An Intervention Study among Israeli Palestinian Kindergartners. Applied Psycholinguistics, 29, 413-436.

Saiegh-Haddad, E., Levin, I., Hende, N., \& Ziv, M. (2011). The Linguistic Affiliation Constraint and Phoneme Recognition in Diglossic Arabic. Journal of Child Language, 38, 279-315.

Schneider, W., Kuspert, P., Roth, E., Vise, M., \& Marx, H. (1997). Short- and Long-Term Effects of Training Phonological Awareness in Kindergarten: Evidence from Two German Studies. Journal of Experimental Child Psychology, 66, 311-340. https://doi.org/10.1006/jecp.1997.2384

Serrano, F., \& Defior, S. (2008). Dyslexia Speed Problems in a Transparent Orthography. Annals of Dyslexia, 58, Article No. 81. https://doi.org/10.1007/s11881-008-0013-6

Shany, M., Bar-On, A., \& Katzir, T. (2012). Reading Different Orthographic Structures in the Shallow Pointed Hebrew Script: Across-Grade Study in Elementary School. Reading and Writing, 25, 1217-1238. https://doi.org/10.1007/s11145-011-9314-y

Share, D. L. (2008). On the Anglocentricities of Current Reading Research and Practice: The Perils of Overreliance on an "Outlier" Orthography. Psychological Bulletin, 134, 584-615. https://doi.org/10.1037/0033-2909.134.4.584

Taha, H. (2013). Investigation Cognitive Processes Underlying Reading in Arabic: Evidence from Typical and Poor Reading Performance. Psychology, 4, 1018-1026. https://doi.org/10.4236/psych.2013.412148

Treiman, R., \& Baron, J. (1983). Phonemic-Analysis Training Helps Children Benefit from Spelling-Sound Rules. Memory and Cognition, 11, 382-389.

https://doi.org/10.3758/BF03202453

Van Orden, G. C., Pennington, B. F., \& Stone, G. O. (1990). Word Identification in Reading and the Promise of Subsymbolic Psycholinguistics. Psychological Review, 97, 488-522. 


\section{Appendices}

\section{Appendix 1-Examination No. 1}

\section{Translation into Modern Standard Arabic}

1) امبيرح رَوّحنا بَّربي من المدرسة.

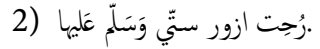

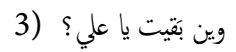

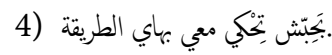

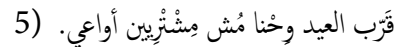

6عزَمت بنات صني على عيد ميلادي يوم المحميس الجاي.

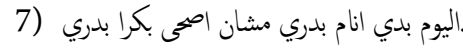

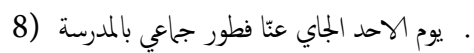

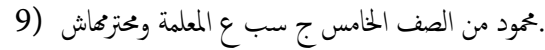

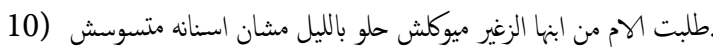

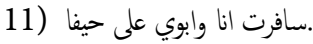

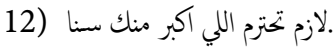

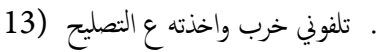

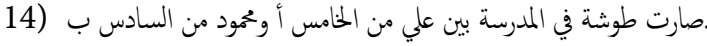

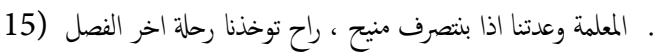

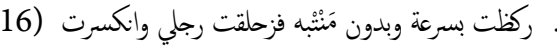

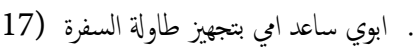

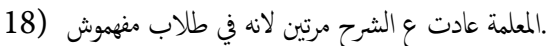

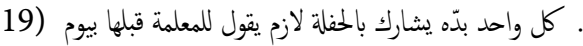

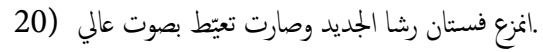

\section{Appendix 2-Examination No. 2}

Cloze. Complete the sentence by filling in the missing word.

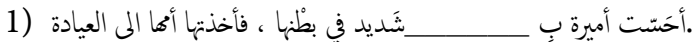

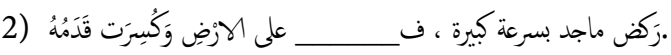
3) بكى عليّ تَّم قال : بطني

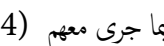

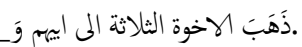
5) كلّ يون (5)

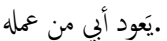

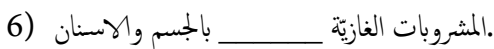

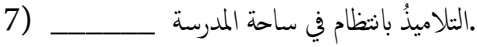

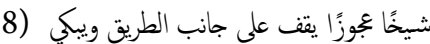

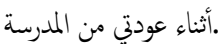
9)

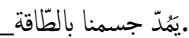

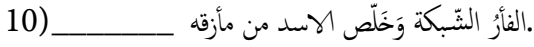

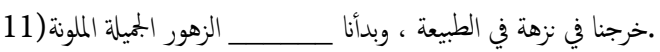

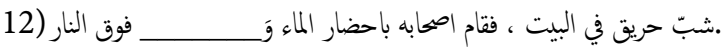

13)

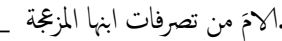

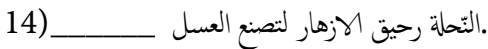

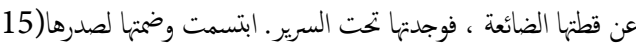

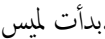

16)

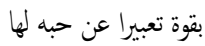

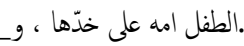


17)

18)

رشا من مكانها من شدة الفرح ، عندما اخبرها والدها أنه ينوي شراء جرو جديد لها.

19)

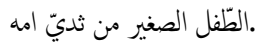

20)

الشمس في الصباح الباكر وتغرب وقت المساء الصغي منيّ الهاء.

Appendix 3-Oral Expression
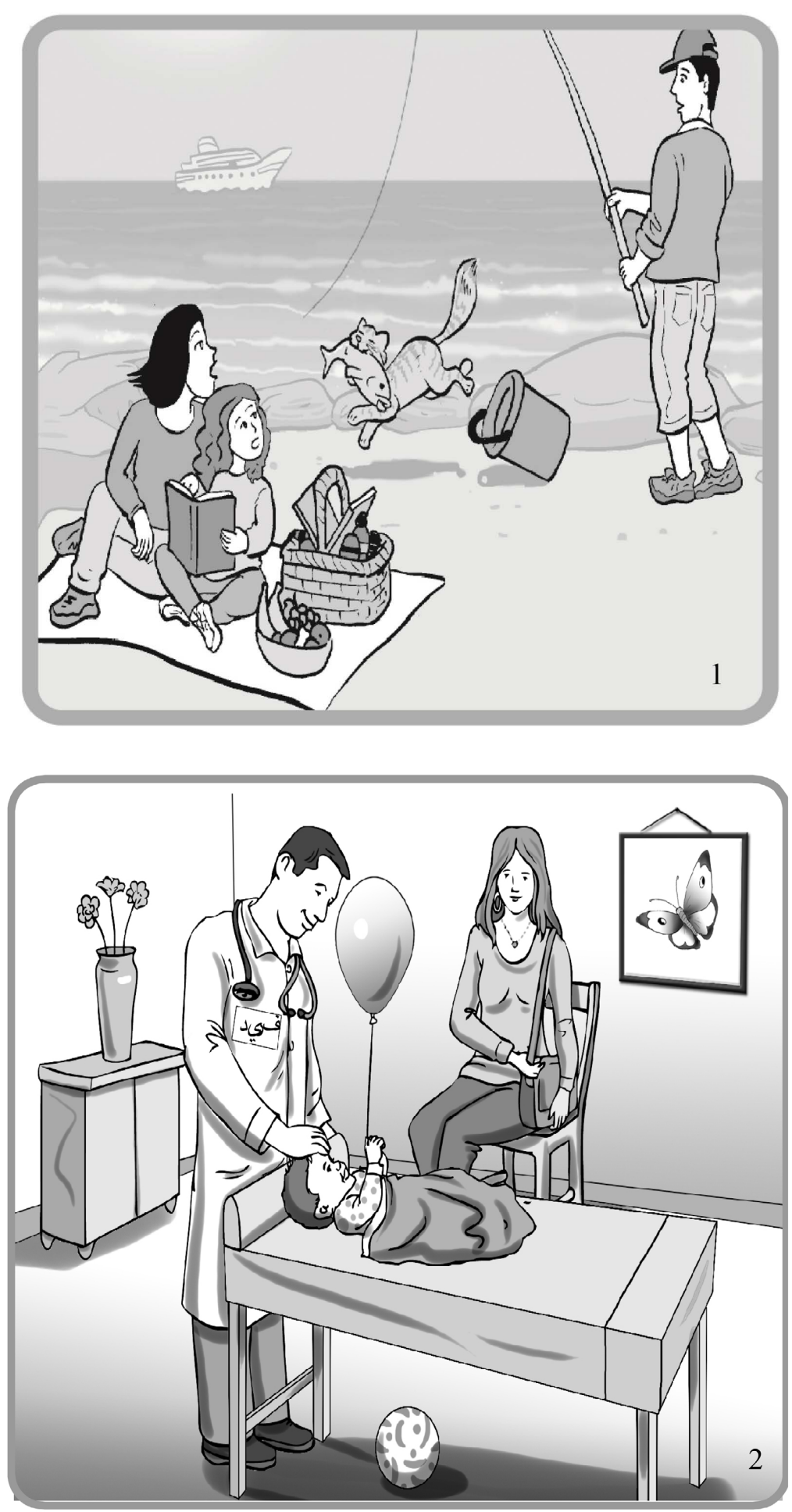

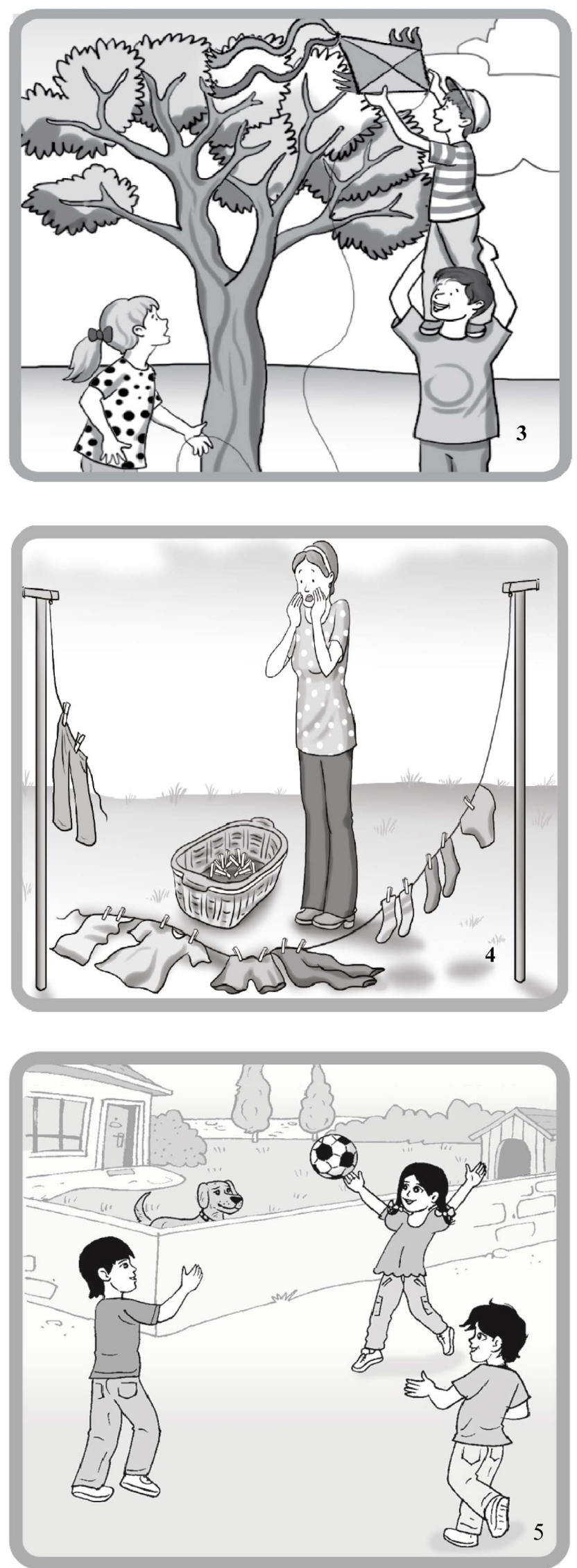

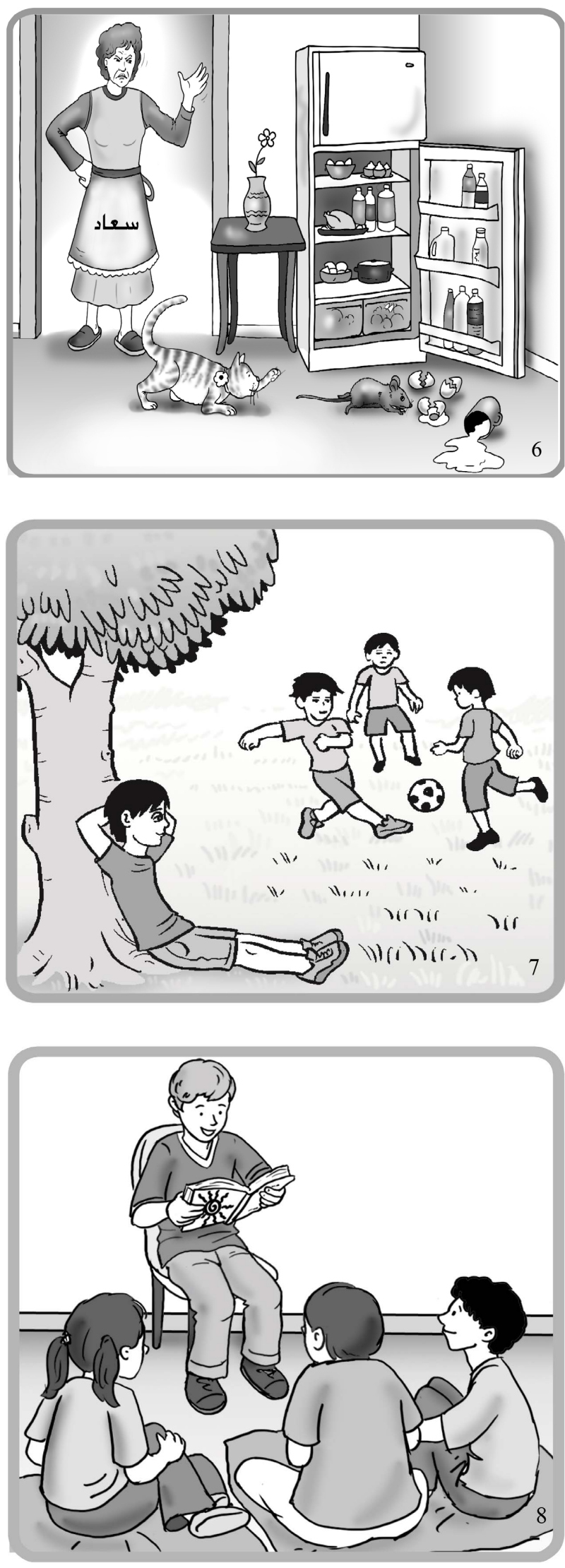